Conclusions $\mathrm{T}+\mathrm{O}$ FDCs were safe and well tolerated. In comparison to the individual components, there was no notable increase in AEs with $\mathrm{T}+\mathrm{O}$ FDCs.

\section{P257 SUB-OPTIMAL INHALER TECHNIQUE IN PATIENTS AGED OVER 75 YEARS}

${ }^{1} S$ Vandermolen, ${ }^{2} \mathrm{~J}$ Berner, ${ }^{1} \mathrm{M}$ Almond, ${ }^{1} \mathrm{~F}$ Huwez. ${ }^{1}$ Southend University Hospital, Essex, UK: ${ }^{2}$ Barts and the London Medical School, London, UK

\subsection{6/thoraxjnl-2014-206260.385}

Introduction and objectives NICE guidelines highlight the importance of adequate inhaler technique to ensure sufficient drug delivery in asthma and C. O. P. D. Whilst adequate inhaler technique can be a problem for patients of any age, the delivery of inhaled medication continues to be a particular problem for elderly patients. Despite the existence of pressurised metereddose inhalers and breath-actuated inhalers, physical and cognitive impairment continues to make the use of hand-held inhalers difficult in the elderly. It is therefore likely that inhaler use in the elderly is suboptimal, regardless of device used.

Methods We assessed 50 consecutive patients aged over 75 years with C. O. P. D or asthma at our centre (mean age $78.24 \pm$ 7.32). All had inhaler therapy prescribed prior to examination. Two observers assessed inhaler technique against guidelines adapted from the National Asthma Council of Australia ${ }^{1}$ (see Table). Patients used either an Evohaler (pressurised metereddose inhaler) or Accuhaler (breath-actuated inhaler) according to their choice.

Results In the Evohaler group (25 patients), the average age was $78( \pm 5.5)$ with an average score of $6.6( \pm 1.81) / 10$. In the Accuhaler group (25 patients), average age was $77( \pm 6.4)$ with an average score of $7.2( \pm 2.0) / 10$. 'Crucial' steps to adequate inhaler technique were also assessed. ${ }^{2}$ The score in the Evohaler group was $4.4( \pm 1.2) / 6$, and in the Accuhaler group was 4.3 $( \pm 1.0) / 6$.

Conclusion This study shows that despite the availability of both Evohaler (pressurised metered-dose inhaler) and Accuhaler (breath-actuated inhaler) effective use by the elderly is still suboptimal. The very elderly need extra support when considering and prescribing inhalers. Whilst many centres have 'good inhaler technique' as a pillar of their COPD care bundle, it may be the case that specialist services, including the use of specialist devices, directed at the elderly may help to alleviate the problems of physical and cognitive impairment when using inhalers.

\begin{tabular}{lll}
\multicolumn{2}{l}{ Abstract } & P257 Table 1 \\
\hline Step & EVOHALER & ACCUHALER \\
\hline 1 & Remove cap & Open using thumb grip \\
2 & Hold inhaler upright and shake & Load dose by sliding lever until it clicks \\
3 & Breathe out & Breathe out \\
& Put mouthpiece between lips, & Put mouthpiece between lips, \\
4 & close lips to form seal & close lips to form seal \\
5 & Breathe in and press down & Breathe in steadily \\
6 & Continue to breathe in & Continue to breathe in \\
7 & Hold breath 10 secs & Hold breath 10 secs \\
8 & Remove inhaler & Remove inhaler \\
9 & Breathe out & Breathe out \\
10 & Replace cap & Close cover \\
\hline
\end{tabular}

\section{REFERENCES}

1 National Asthma Council Australia. Inhaler technique in adults with asthma or COPD. Melbourne: National Asthma Council Australia, 2008

2 Newman S. P. Inhaler treatment options in COPD. Eur Respir Rev 2005;14 (96):102-108

\section{P258 THE 24-HOUR LUNG FUNCTION PROFILE OF ONCE- DAILY TIOTROPIUM AND OLODATEROL FIXED-DOSE COMBINATION COMPARED WITH PLACEBO AND MONOTHERAPIES IN CHRONIC OBSTRUCTIVE PULMONARY DISEASE}

${ }^{1} \mathrm{E}$ Derom, ${ }^{2} \mathrm{~J}$ Westerman, ${ }^{3} \mathrm{~L}$ Grönke, ${ }^{4} \mathrm{~A}$ Hamilton, ${ }^{5} \mathrm{C} \mathrm{Li},{ }^{6} \mathrm{KM}$ Beeh. ${ }^{1}$ Ghent University Hospital, Ghent, Belgium; '2Pulmonary and Sleep Associates of Jasper, Jasper, Alabama, USA; ${ }^{3}$ Boehringer Ingelheim Pharma GmbH and Co. KG, Ingelheim, Germany; ${ }^{4}$ Boehringer Ingelheim, Burlington, Ontario, Canada; ${ }^{5}$ Boehringer Ingelheim Pharmaceuticals Inc, Ridgefield, Connecticut, USA; ${ }^{6}$ Insaf GmbH Institut Für Atemwegsforschung, Wiesbaden, Germany

\subsection{6/thoraxjnl-2014-206260.386}

Introduction Tiotropium (T), a once-daily long-acting muscarinic antagonist, is a well-established first-line maintenance treatment in chronic obstructive pulmonary disease (COPD). Olodaterol $(\mathrm{O})$ is a once-daily long-acting $\beta_{2}$-agonist, recently approved in several EU countries. This study investigated the 24-hour bronchodilator profile of once-daily fixed-dose combinations (FDCs) of $\mathrm{T}$ and $\mathrm{O}$ delivered via the Respimat ${ }^{\circledR}$ Soft Mist $^{\mathrm{TM}}$ inhaler in patients with Global initiative for chronic Obstructive Lung Disease 2-4 COPD.

Methods This double-blind, placebo-controlled, Phase III, incomplete crossover study randomised 219 patients to receive four of the following treatments for 6 weeks (with a 3-week washout period in between): placebo, O $5 \mu \mathrm{g}, \mathrm{T} 2.5 \mu \mathrm{g}$, T $5 \mu \mathrm{g}$, $\mathrm{T}+\mathrm{O}$ FDC $2.5 / 5 \mu \mathrm{g}, \mathrm{T}+\mathrm{O}$ FDC $5 / 5 \mu \mathrm{g}$. The primary end point was forced expiratory volume in 1 second $\left(\mathrm{FEV}_{1}\right)$ area under the curve from $0-24 \mathrm{~h}\left(\mathrm{AUC}_{0-24}\right)$ after 6 weeks. Secondary end points included additional spirometric parameters over $24 \mathrm{~h}$ and body plethysmography parameters in a sub-set of patients $(2: 30$ and 22:30 h post-dose).

Results The 24-hour time profiles for both FDCs were similar, with clear, consistent increases in $\mathrm{FEV}_{1}$ compared to placebo and monotherapies. For $\mathrm{FEV}_{1} \mathrm{AUC}_{0-24}$, both FDCs were significantly superior to placebo $(\mathrm{T}+\mathrm{O} 5 / 5 \mu \mathrm{g}$ : $0.280 \mathrm{~L}, \mathrm{p}<0.0001$; $\mathrm{T}+\mathrm{O} 2.5 /$ $5 \mu \mathrm{g}: 0.277 \mathrm{~L}, \mathrm{p}<0.0001)$ and monotherapies $(\mathrm{T}+\mathrm{O} 5 / 5 \mu \mathrm{g}$ : 0.110-0.127 L, p < 0.0001; T+O 2.5/5 $\mu \mathrm{g}: 0.107-0.124 \mathrm{~L}, \mathrm{p}<$ 0.0001). There were significantly greater increases in trough $\mathrm{FEV}_{1}$ with both FDCs compared to placebo (0.201-0.207 L, p < 0.0001) and monotherapies (T+O 5/5 $\mu \mathrm{g}$ : 0.079-0.107 L, p < 0.0001; T+O 2.5/5 $\mu \mathrm{g}: 0.073-0.101 \mathrm{~L}, \mathrm{p}<0.0001)$. In the body plethysmography sub-study, both FDC doses separated from

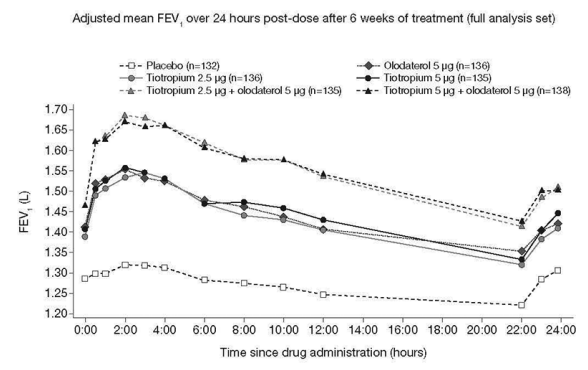

Abstract P258 Figure 1 Adjusted mean Fev 1 over $24 \mathrm{~h}$ post dose after 6 weeks of treatment (full analysis set) 
placebo and monotherapies in functional residual capacity $(\mathrm{p}<$ $0.001)$ and residual volume $(\mathrm{p}<0.0001)$. Both FDCs were well tolerated; overall incidence of adverse events ranged between $36.0 \%(\mathrm{~T}+\mathrm{O} 2.5 / 5 \mu \mathrm{g})$ and $46.4 \%$ (placebo).

Conclusions Both FDC 24-hour time profiles showed clear and consistent increases in $\mathrm{FEV}_{1}$ compared to placebo and monotherapies, with a similar tolerability profile to $\mathrm{T}$.

\section{P259 TIOTROPIUM HANDIHALER® AND RESPIMAT® IN COPD: A SAFETY ANALYSIS ON POOLED DATA}

${ }^{1}$ DMG Halpin, ${ }^{2} \mathrm{R}$ Dahl, ${ }^{3} \mathrm{C}$ Hallmann, ${ }^{3} \mathrm{~L}$ Leimer, ${ }^{3} \mathrm{~A}$ Mueller, ${ }^{4} \mathrm{DP}$ Tashkin. ${ }^{1}$ Royal Devon and Exeter Hospital, Exeter, UK; ${ }^{2}$ Odense University Hospital, Odense, Denmark; ${ }^{3}$ Boehringer Ingelheim Pharma GmbH and Co. KG, Ingelheim, Germany; ${ }^{4}$ David Geffen School of Medicine UCLA, Los Angeles, California, USA

\subsection{6/thoraxjnl-2014-206260.387}

Rationale Tiotropium has been approved and marketed via HandiHaler ${ }^{\circledR}(18 \mu \mathrm{g}$ once daily [qd]) since 2002 and via Respimat ${ }^{\circledR}(5 \mu \mathrm{g} \mathrm{qd})$ since 2007 . The recent TIOSPIR ${ }^{\mathrm{TM}}$ (TIOtropium Safety and Performance In Respimat $\left.{ }^{\circledR}\right)$ study demonstrated that both products had comparable safety profiles; the objective of this analysis was to provide an updated safety evaluation of tiotropium in both formulations.

Methods Analysis of pooled adverse events (AEs) from randomised, double-blind, parallel-group, placebo-controlled clinical trials of $\geq 4$ weeks' duration where either tiotropium HandiHaler ${ }^{\circledR} 18 \mu \mathrm{g}$ or tiotropium Respimat ${ }^{\circledR} 5 \mu \mathrm{g}$ was indicated for chronic obstructive pulmonary disease (COPD). Rate ratios (RRs), incidence rates (IRs) and 95\% confidence intervals (CIs) were determined for HandiHaler ${ }^{\circledR}$ and Respimat ${ }^{\circledR}$ trials together and separately.

Results This analysis of 28 HandiHaler ${ }^{\circledR}$ and seven Respimat ${ }^{\circledR}$ studies provided 14,909 (12,469 and 2440 with HandiHaler ${ }^{\circledR}$ and Respimat ${ }^{\circledR}$, respectively) patient-years' exposure to tiotropium. Mean age was 65 years and mean forced expiratory volume in 1 second was $1.16 \mathrm{~L}$ (41\% predicted). The risk (RR $[95 \% \mathrm{CI}])$ of AEs $(0.90[0.87,0.93])$ and serious AEs (0.94 $[0.89,0.99])$ was significantly lower with a numerically lower risk of death $(0.90[0.79,1.01])$ in the tiotropium group (pooled results) (Table). When separated by device, the risk of AEs and serious AEs remained lower in the tiotropium groups than placebo: RR 0.88 and 0.94 for HandiHaler ${ }^{\circledR}$ and 0.94 and 0.94 for Respimat ${ }^{\circledR}$ for AEs and serious AEs, respectively. Risks for cardiac events $(0.93[0.85,1.02])$ and major adverse cardiovascular events (MACE) $(0.87$ [0.75, 1.01]) were numerically lower and risk for respiratory, thoracic and mediastinal disorders $(0.76$ $[0.61,0.96])$ was significantly reduced in the tiotropium group. The typical anticholinergic effects of dry mouth (2.39 [2.01,

\begin{tabular}{|c|c|c|c|c|c|}
\hline & \multicolumn{2}{|c|}{ Placebo $(n=11,626)$} & \multicolumn{2}{|c|}{ Tiotropium $(n=12,929)$} & \multirow[t]{2}{*}{ RR $(95 \% \mathrm{Cl})$} \\
\hline & $\mathrm{n}(\%)$ & IR & n (\%) & IR & \\
\hline AEs & 7619 (65.5) & 152.85 & 8093 (62.6) & 140.35 & $0.90(0.87,0.93)^{*}$ \\
\hline Serious AEs & $2654(22.8)$ & 23.08 & $2802(21.7)$ & 21.73 & $0.94(0.89,0.99)^{*}$ \\
\hline Fatal AEs & $523(4.5)$ & 3.71 & $515(4.0)$ & 3.27 & $0.90(0.79,1.01)$ \\
\hline MACE & $358(3.1)$ & 2.56 & $345(2.7)$ & 2.20 & $0.87(0.75,1.01)$ \\
\hline Fatal $\mathrm{MACE}^{\dagger}$ & $192(1.7)$ & 1.35 & $190(1.5)$ & 1.20 & $0.90(0.74,1.10)$ \\
\hline
\end{tabular}

2.84]), constipation (1.28 [1.06, 1.54]), intestinal obstruction (3.80 [1.42, 10.12]), dysuria (2.16 [1.31, 3.57]) and urinary retention $(1.93$ [1.21, 3.09]) were higher in the tiotropium group.

Conclusions The results from this safety review do not indicate an increased overall risk for fatal or cardiovascular events during tiotropium treatment, given via HandiHaler ${ }^{\circledR}$ or Respimat ${ }^{\circledR}$, in patients with COPD.

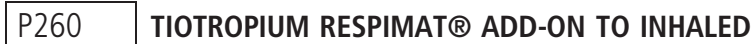 CORTICOSTEROIDS IMPROVES LUNG FUNCTION IN PATIENTS WITH SYMPTOMATIC MILD ASTHMA: RESULTS FROM A PHASE III TRIAL}

${ }^{1} \mathrm{P}$ Paggiaro, ${ }^{2} \mathrm{DMG}$ Halpin, ${ }^{3} \mathrm{R}$ Buhl, ${ }^{4} \mathrm{M}$ Engel, ${ }^{5} \mathrm{VB}$ Zubek, ${ }^{6} \mathrm{Z}$ Blahova, ${ }^{4} \mathrm{P}$ Moroni-Zentgraf, ${ }^{7}$ E Pizzichini. ${ }^{1}$ University of Pisa, Pisa, Italy; ${ }^{2}$ Royal Devon and Exeter Hospital, Exeter, UK; ${ }^{3}$ Mainz University Hospital, Mainz, Germany; ${ }^{4}$ Boehringer Ingelheim Pharma GmbH and Co. KG, Ingelheim Am Rhein, Germany; ${ }^{5}$ Boehringer Ingelheim Pharmaceuticals, Inc., Ridgefield, USA; ${ }^{6}$ Boehringer Ingelheim RCV GmbH and Co. KG, Vienna, Austria; ${ }^{7}$ NUPAIVA (Asthma Research Centre), Universidade Federal de Santa Catarina, Florianópolis, Santa Catarina, Brazil

\subsection{6/thoraxjnl-2014-206260.388}

Background Despite currently available therapies and detailed guidelines, many people with mild asthma remain symptomatic; it is important to establish the efficacy and safety of new treatments in this group.

Methods A Phase III, randomised, double-blind, parallel-group trial (GraziaTinA-asthma ${ }^{\circledR}$; NCT01316380) evaluated the efficacy and safety of once-daily tiotropium $5 \mu \mathrm{g}$ or $2.5 \mu \mathrm{g}$ versus placebo (all delivered via the Respimat ${ }^{\circledR}$ SoftMist ${ }^{\mathrm{TM}}$ inhaler) for 12 weeks in patients with symptomatic asthma on low-dose inhaled corticosteroids (200-400 $\mu \mathrm{g}$ budesonide or equivalent). The primary end point was peak forced expiratory volume in 1 second $\left(\mathrm{FEV}_{1}\right)$ within $3 \mathrm{~h}$ of dosing $(0-3 \mathrm{~h})$ response (change from baseline) at 12 weeks. Secondary end points were trough $\mathrm{FEV}_{1}, \mathrm{FEV}_{1}$ area under the curve $(\mathrm{AUC})_{(0-3 \mathrm{~h})}$ and peak expiratory flow responses (measured with the $\mathrm{AM} 2+{ }^{\circledR}$ device), and seven-question Asthma Control Questionnaire (ACQ-7) score.

Results Of 464 treated patients, 155 received tiotropium Respimat ${ }^{\circledR} 5 \mu \mathrm{g}, 154$ received tiotropium Respimat ${ }^{\circledR} 2.5 \mu \mathrm{g}$ and 155 received placebo Respimat ${ }^{\circledR}$. Both tiotropium Respimat ${ }^{\circledR}$ doses were superior to placebo Respimat ${ }^{\circledR}$ in peak $\mathrm{FEV}_{1(0-3 \mathrm{~h})}$ response (adjusted mean difference: $5 \mu \mathrm{g}, 128 \mathrm{~mL} ; 2.5 \mu \mathrm{g}, 159 \mathrm{~mL}$; both $\mathrm{p}<0.001$ ) and trough $\mathrm{FEV}_{1}$ response (adjusted mean difference: $5 \mu \mathrm{g}, 122 \mathrm{~mL}, \mathrm{p}=0.001 ; 2.5 \mu \mathrm{g}, 110 \mathrm{~mL}, \mathrm{p}=0.003) . \mathrm{FEV}_{1}$ $\mathrm{AUC}_{(0-3 \mathrm{~h})}$ response at each visit, versus placebo Respimat ${ }^{\circledR}$, significantly favoured tiotropium Respimat ${ }^{\circledR} 5 \mu \mathrm{g}(\mathrm{p}=0.009$ to $\mathrm{p}$ $<0.001$ ) and $2.5 \mu \mathrm{g}$ (all $\mathrm{p}<0.001$, except Day 1). Adjusted mean morning and evening peak expiratory flow responses, versus placebo Respimat ${ }^{\circledR}$, each week, all favoured tiotropium Respimat ${ }^{\circledR} 5 \mu \mathrm{g}$ (all $\mathrm{p}<0.001$ ) and $2.5 \mu \mathrm{g}$ (all $\mathrm{p}<0.003$ ). Adjusted mean ACQ-7 score was similar across all arms (tiotropium Respimat ${ }^{\circledR} 5 \mu \mathrm{g}, 1.391$; tiotropium Respimat ${ }^{\circledR} 2.5 \mu \mathrm{g}$, 1.438; placebo Respimat ${ }^{\circledR}, 1.377$ ). Adverse events were predominantly mild or moderate and were balanced between treatment groups.

Conclusion Tiotropium Respimat ${ }^{\circledR}$ was effective and well tolerated in patients with symptomatic mild asthma despite low-dose inhaled corticosteroid treatment. 